\title{
DISSOLVED NUTRIENT FLUXES IN MACROTIDAL ESTUARY IN THE AMAZONIAN REGION, BRAZIL
}

\author{
Thays Thayanne Luz SANTOS ${ }^{1,3}$ *; Jefferson Horley Feitosa SEREJO2; Hugo Pereira LIMA ${ }^{2}$; \\ Samara Aranha ESCHRIQUE ${ }^{3}$
}

\begin{abstract}
${ }^{1}$ Programa de Pós-graduação em Ciências Marinhas Tropicais, Universidade Federal do Ceará, Instituto de Ciências do Mar/LABOMAR, Av. da Abolição, 3207, Zip code 60.165-081, Fortaleza, CE, Brazil. E-mail: thays luzsantos@hotmail.com

* Corresponding author

${ }^{2}$ Instituto de Ciências do Mar/ ICMar, Universidade Federal do Maranhão, Av. dos Portugueses Bacanga, 1966, Zip code 65.058-205, São Luís, Maranhão, Brazil. E-mail: jefferson.hfs@gmail.com, limahugo@hotmail.com
\end{abstract}

${ }^{3}$ Departamento de Oceanografia e Limnologia, Universidade Federal do Maranhão, Av. dos Portugueses Bacanga, 1966, Zip code 65.058-205, São Luís, Maranhão, Brazil. E-mail: samara.eschrique@gmail.com

\begin{abstract}
This paper aimed to characterize the transport of dissolved nutrients through São Marcos Bay, in Brazilian Amazonian region, and to understand if it acts as a sink or a source of dissolved nutrients for the adjacent marine system of the region. Water sample collections were distributed in two profiles (P1 and P2) in different seasons: dry and rainy. River discharge, temperature, $\mathrm{pH}$, salinity, dissolved oxygen and turbidity were measured in situ. Dissolved nutrients in the water, such as the nitrite, phosphate and silicate were determined with colorimetric method. During the dry season, when occured the flood tide in the estuary, salinity and $\mathrm{pH}$ increased and the other parameters decreased, because of the processes occurring in water are commonly connected by acid-base reactions and oxidation-reduction in the environment. During the rainy season the inverse process occurred, due to rainfall intensity in the region. All the nutrient fluxes had same variability in P1, both spatial and temporal, obtaining the highest values during the rainy season. Whereas P2 showed different variations of the fluxes, indicating that most nutrients that entered the estuarine were retained between profiles, suggesting that the São Marcos Bay acts predominately as a nutrient sink from the draining basin.
\end{abstract}

Keywords: nitrite, phosphate, silicate, water, São Marcos Bay.

Resumo. O estudo tem como objetivo caracterizar o transporte de nutrientes dissolvidos na Baía de São Marcos, na região Amazônica brasileira, e compreender se o ambiente funciona como um sumidouro ou fonte de nutrientes dissolvidos para a região do sitema marinho adjacente. Coletas de amostras de águas foram distribuídas em dois perfis ( $\mathrm{P} 1$ e $\mathrm{P} 2$ ) em diferentes períodos sazonais: seco e chuvoso. Descarga do rio, temperatura, $\mathrm{pH}$, salinidade, oxigênio dissolvido e turbidez foram mensurados in situ. Nutrientes dissolvidos na água, como nitrito, fosfato e silicato foram determinados pelo método colorimétrico. No período chuvoso, durante a maré de enchente no estuário, a salinidade e pH aumentam e os outros parâmetros diminuíram devido aos processos que ocorrem na água são comumente relacionados às reações ácido-base e oxirredução no ambiente. Durante o período chuvoso, o processo inverso occorreu, devido a intensa precipitação na região. Observou-se que o P2 mostrou diferentes variações nos fluxos, indicando que a maioria dos nutrientes que entraram no estuário ficaram retidos entre os perfis de coletas, sugerindo que a Baía de São Marcos funciona predominantemente como um sumidouro de nutrientes originados da bacia de drenagem.

Palavras-chaves: nitrito, fosfato, silicato, água, Baía de São Marcos. 


\section{INTRODUCTION}

Tropical estuarine environments such as bays, coastal lagoons and mangroves are firmly subject to expansion and urban growth (Silva et al., 2015). These ecosystems work as corridors for the transport of dissolved or suspended continental matters (nutrients and organic matter) towards the sea. In addition, they represent deposition zones, functioning as true "filters" for some chemical compounds (Silva, 2007).

There are numerous sources of nutrients to estuaries, from land-based point and nonpoint sources, to atmospheric and groundwater inputs (Gilbert et al., 2010). Phosphorus and nitrogen forms are found amply available in estuaries that develop important role for biological processes, such as the primary production (Demaster and Pope, 1996; Howarth et al., 2011; Wang et al., 2014).

The load of nutrients in estuaries, nitrogen $(N)$ and phosphorus $(P)$, has been increasing as a result of an expanding human population in the draining basin, while the load of silicate has not followed this trend because it is less influenced by human activities (Falco et al., 2010). The rapid nutrient input in the estuary can alters the natural biogeochemical cycles, resulting in eutrophication process and alteration in the environment quality.

Studies about nutrient dynamics along Brazilian Northeast estuaries are limited, as the case of Sao Marcos Bay in Maranhão state (Azevedo et al., 2008; De Carvalho et al., 2000). It is an estuarine complex located between the transition of Amazonian and semi-arid Brazilian climate (Teixeira and Souza Filho, 2009). The channel is considered the second deepest in the world, making harbor activity with very important for the economy of the region (Feres, 2010; Sant'Ana Júnior, 2016), followed by agriculture, livestock and tourism.

Itaqui Harbor, Ponta da Madeira terminal and Alumar terminal consist the harbor complex that exports ore, fertilizers, grains, steel and aluminum. Ponta da Madeira terminal is undergoing an expansion to increase its export capacity to 235 millions of tons per year of iron mineral, becoming the port with the largest volume of cargo in Brazil (González-Gorbeña et al., 2015).

Considering the anthropogenic pressure on São Marcos Bay, the nutrient flux study is an essential tool to examine the relative importance of external nutrient inputs versus physical transports and internal biogeochemical processes (Wang et al., 2014). Therefore, this paper aimed to characterize the transport of dissolved nutrients through São Marcos Bay, and to understand if it acts as a sink or a source of dissolved nutrients for the adjacent marine system of the region. 


\section{MATERIAL AND METHODS \\ ENVIRONMENTAL SETTING}

São Marcos Bay (SMB) is a macrotidal estuary located in Maranhão state, over the Brazilian transition zone between the northeastern semi-arid and the hot and humid Amazonian region. It is situated in the center of Golfão Maranhense along with the Bay of São José, that is divided by the Maranhão Island (Fig. 1). The climate of the region is tropical, characterized by two very distinct seasonal periods: rainy season (January to June) and dry season (July to December), with total annual rainfall over 2,000 mm (Azevedo et al., 2008).

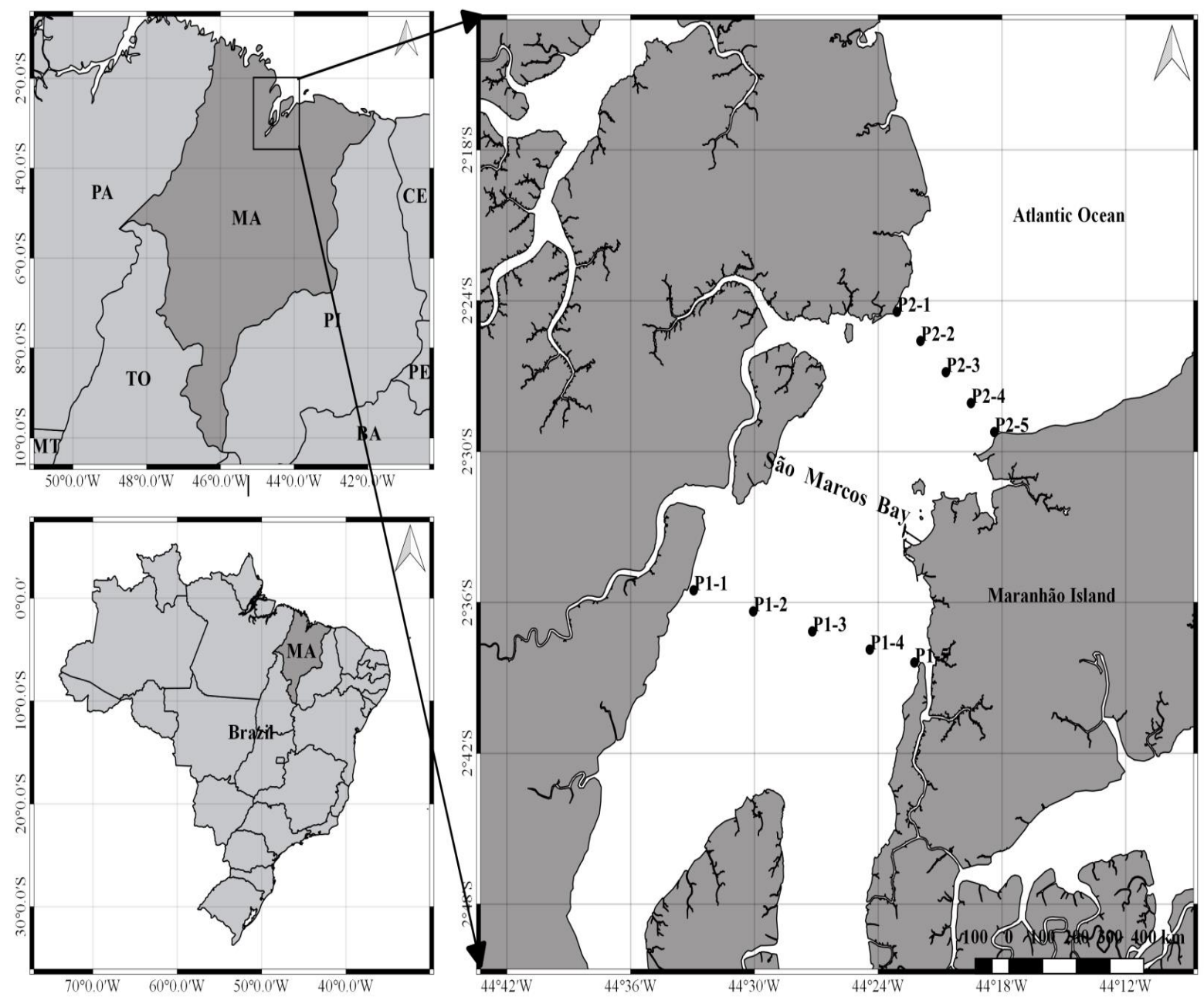

Figure 1. Location map of samplings sites in the São Marcos Bay, Maranhão, Brazil.

SMB has a central channel with depths up to $90 \mathrm{~m}$ and a width of $\sim 55 \mathrm{~km}$, which narrows to $1.5 \mathrm{~km}$ at the intersection of Pindaré and Mearim rivers. It has the biggest mangrove area of the country with 5,414.31 km2 (Cavalcanti et al., 2018; Rodrigues et al., 2016). It is characterized by semi-diurnal tidal, with tidal current speeds up to $2.5 \mathrm{~m} \mathrm{~s}-1$ that influences areas up to $150 \mathrm{~km}$ from the coast (Chagas, 2013; De Morais, 1977). According to El-Robrini et 
al. (2006), SMB presents a tide regime of approximately 25 hours duration that reaches the maximum velocity of current in the third hour of flood and in the third hour of ebb, decreasing proportionally until the slack water of high tide and low tide.

\section{SAMPLING AND ANALYTICAL PROCEDURES}

Two campaigns were carried out in distinct seasonal periods. The first one took place on November 3rd, 2014 during the dry season, and the second one was carried out on June 11st, 2015 in the rainy season. Two profiles (P1 and P2) were determined along the estuarine complex with five sampling site each. The P1 is located downstream of the environment between $2^{\circ} 35^{\prime} 31^{\prime \prime S} 44^{\circ} 32^{\prime} 56^{\prime \prime} \mathrm{W}$ and $2^{\circ} 38^{\prime} 01^{\prime \prime S} 44^{\circ} 24^{\prime} 0^{\prime \prime} \mathrm{W}$, and profile P2 is upstream of the environment along $2^{\circ} 24^{\prime} 26^{\prime \prime S} 44^{\circ} 23^{\prime} 5^{\prime \prime}$ and $2^{\circ} 29^{\prime} 13^{\prime \prime S} 44^{\circ} 18^{\prime} 22^{\prime \prime} \mathrm{W}$. The profiles present 21 and $13 \mathrm{~km}$ of extension, respectively.

To determinate the sample depths, the Acoustic Doppler Current Profiler (Sontek/YSI, California, USA) was used with a frequency of $1500 \mathrm{MHz}$. In those places where the sample depth exceeded the maximum tidal height $(7.0 \mathrm{~m})$, the water samples were collected on surface, middle and bottom of the water column. The places in which depth was below the limit, only surface and bottom were collected. Duplicates of water samples were collected with a van Dorn bottle of $5 \mathrm{~L}$. The water samples were stored in polyethylene bottles of $500 \mathrm{~mL}$ and refrigerated in Styrofoam with ice and transported for chemical analyzes at laboratory.

Temperature and salinity were measured in situ with CTD apparatus (Exo2 Multiparameter Sonde, YSI, Ohio, USA). Dissolved oxygen (OD) and Hydrogenionic potential $(\mathrm{pH})$ were

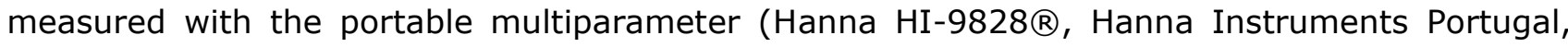
Povoa de Varzim, POR), with accuracy of $\pm 0.01 \mathrm{pH}$ units. Turbidity was obtained with digital turbidity meter (TB1000, MS Tecnopon, Piracicaba, BR). All equipaments were previously calibrated with the standard solutions of the apparatus

The monthly rainfall data of the study area were obtained by Instituto Nacional de Meteorologia - INMET. The tide tables were acquired by the Diretoria de Hidrografia e Navegação - DHN of Itaqui Port station. The current speeds were determinated by Acoustic Doppler Current Profiler (ADCP). The velocity vector was decomposed, relative to the cartesian coordinate plane Oxy. After a vector decomposition, the components were delimited by the $\mathrm{i}$-th depth of each point in each hour. The water discharge in the profile to the mean flow of the area were calculated by the numerical integration of the equation of Miranda et al. (2012).

Water samples were filtered by vacuum filtration with $47 \mu \mathrm{m}$ diameter glass fiber filters and nominal $2.0 \mu \mathrm{m}$ porosity. Dissolved inorganic nutrients, such as nitrite (NO2-), phosphate (PO43-) and silicate $(\mathrm{Si}(\mathrm{OH}) 4)$ were determined by the colorimetric method described by Grasshoff et al. (1999), with the spectrophotometer (CARY 300 Conc UV-Visible 
Spectrophotometer, Agilent Technologies, California, USA). These methods have precision of \pm $0.02 \mu \mathrm{mol} \mathrm{L-1}$ for NO2-, $\pm 0.01 \mu \mathrm{mol} \mathrm{L}-1$ for PO4 3 - and $\pm 0.1 \mu \mathrm{mol} \mathrm{L}-1$ for $\mathrm{Si}(\mathrm{OH}) 4$. The product of the water discharge by the average concentration of the nutrients in each depth, estimated the nutrient fluxes of each profile. STATISTICA software version 8.0 was utilized to apply multivariate statistical analysis on the parameters. Shapiro-Wilk test was used to test the normality of the data. Levene Test was applied to analyses the homogeneity of the variances. After this verification, ANOVA one-way (parametric) and Kruskal-Wallis (non-parametric) tests were utilized to observe no significant differences of the parameters among the depths. Student's t-test was applied to observe difference of the variables between the seasons. The significance value used for the tests was 95\% $(p<0.05)$. Principal Component Analysis (PCA) was used to verify the correlation of all physical and chemical parameters in each season.

\section{RESULTS}

\section{RAINFALL AND WATER DISCHARGE CHARACTERIZATION}

All the campaigns occurred under neap tidal conditions, with the range of 0.9 to $6.0 \mathrm{~m}$ during the dry season, and from 1.0 to $5.7 \mathrm{~m}$ during the rainy season. Monthly mean historical rainfall obtained through the period of 1961 to 2014 for Maranhão Island is present in Fig. 2 The months of the campaigns, November 2014 and June 2015, the record represented $81.0 \%$ and $40.6 \%$ below historical mean (respectively), but with no significant seasonal difference (Kruskal-Wallis test; $p=0.443 ; a=0.05$ ). During the campaigns was recorded cumulative rainfall of 2.2 and $0.0 \mathrm{~mm}$ in the dry season and 203.7 and $0.2 \mathrm{~mm}$ in the rainy season, over the previous 30 days and in the collection days.

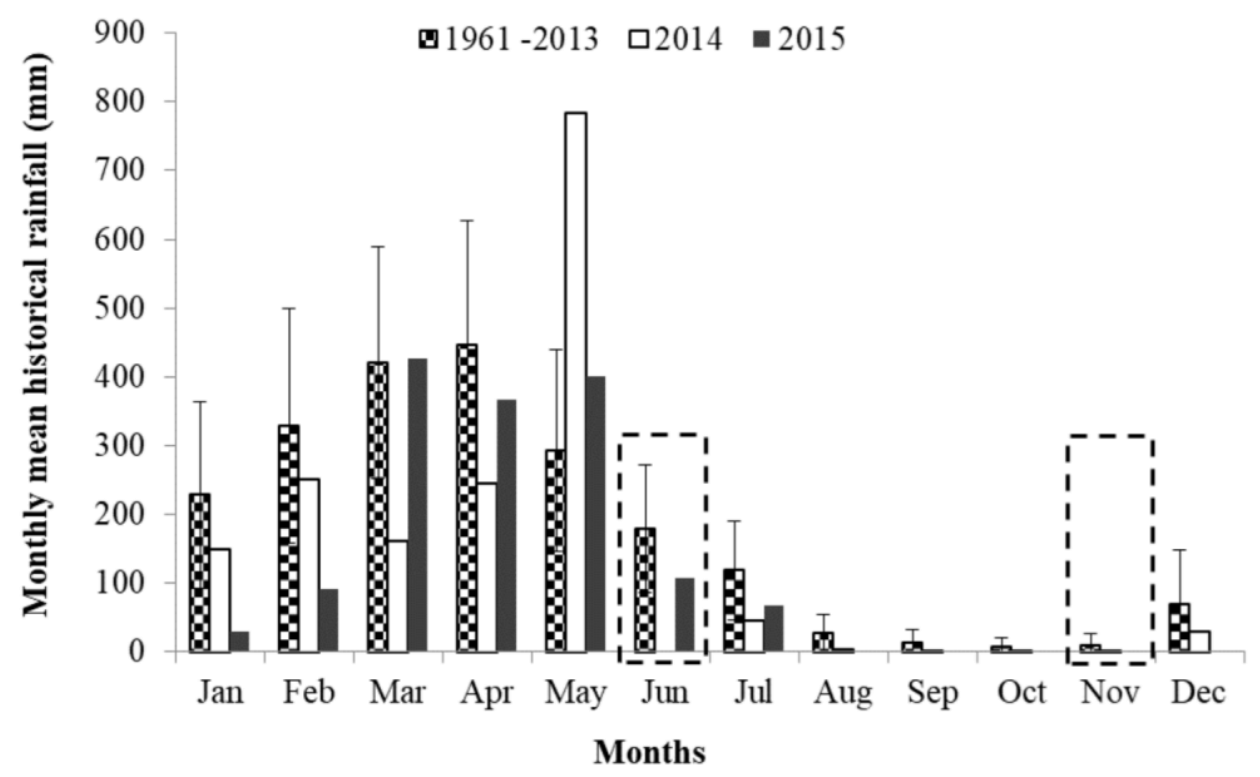

Figure 2. Monthly mean historical rainfall (mm) of Maranhão Island during the period 1961 to 2015 (INMET, 2016). 
Estimated water discharge for the dry season was $0.53 \times 10^{5} \mathrm{~m}^{3} \mathrm{~s}^{-1}$ at $\mathrm{P} 1$, and $0.17 \times 10^{5}$ $\mathrm{m}^{3} \mathrm{~s}^{-1}$ at P2, with an average of $0.35 \times 10^{5} \mathrm{~m}^{3} \mathrm{~s}^{-1}$ (Fig. 3) During the rainy season, the water discharge at P1 was $1.22 \times 10^{5} \mathrm{~m}^{3} \mathrm{~s}^{-1}$ and $0.47 \times 10^{5} \mathrm{~m}^{3} \mathrm{~s}^{-1}$ at P2, with average of $0.84 \times 10^{5}$ $\mathrm{m}^{3} \mathrm{~s}^{-1}$. It was observed a temporal variation between the two profiles, being the rainy season $43.5 \%$ and $37.1 \%$ higher than the dry season in $\mathrm{P} 1$ and $\mathrm{P} 2$, respectively.

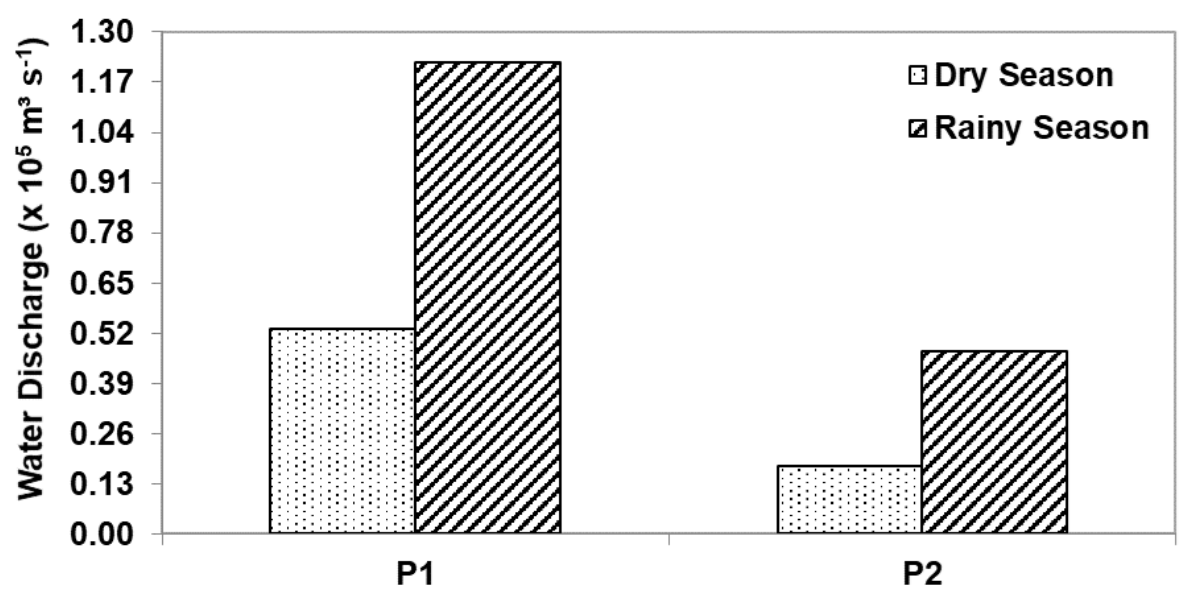

Figure 3. Spatial and temporal variation of water discharge $\left(\times 10^{5} \mathrm{~m}^{3} \mathrm{~s}^{-1}\right)$ of the sample profiles in São Marcos Bay, Maranhão, Brazil.

\section{PHYSICAL AND CHEMICAL CHARACTERIZATION}

Water temperature and salinity were not measured in the 2nd campaign (rainy season), due to technical problems with the sonde. It ranged from 26.6 to $28.1^{\circ} \mathrm{C}$ in the profiles during the dry season. In both profiles, it was observed that the temperatures in the middle of the water column presented slightly higher values compared to surface and bottom waters, although, statistical analyses indicated significant difference among the depths (Kruskal-Wallis test; $p=0.007 ; a=0.05)$, but not along the profiles in the dry season (t-test; $p=0.317$; $a=0.05)$.

Horizontal and vertical distribution of the salinity showed range of 15.5 to $34.2 \mathrm{~g} \mathrm{~kg}^{-1}$ between the profiles during the dry season. Despite the sites P2-3 and P2-4 exhibited low salinity of 15.6 and $15.7 \mathrm{~g} \mathrm{~kg}^{-1}$ (respectively) on the surface, when compared to the other sites of the profiles, statistical analyses showed no significant difference throughout the depths (Kruskal-Wallis test; $p=0.948 ; a=0.05$ ) and profiles (t-test; $p=0.328 ; a=0.05$ ). SMB was characterized as alkaline environment $(\mathrm{pH} \geq 7.5)$, for the reason that $\mathrm{pH}$ values varied from 8.1 to 8.2 in the profiles during the dry season, and from 7.5 to 8.2 over the rainy season. Statistical analyses showed significant differences between the profiles over the rainy season ( $t$ - 
test; $p=0.000 ; a=0.05$ ), but no significant difference among the depths (Kruskal-Wallis test; $p=0.981$, dry; $p=0.988$, rainy; $a=0.05$ ) and seasons (t-test; $p=0.530 ; a=0.05$ ).

DO values range from 3.5 to $5.7 \mathrm{mg} \mathrm{L}^{-1}$ over the dry season, and from 1.8 to $3.1 \mathrm{mg} \mathrm{L}^{-1}$ during the rainy season. Highest DO values were found in P1 in both campaigns, and 47.73\% more oxygenated during the dry season, compared to rainy season. It was observed a significant difference between the profiles in each season (t-test; $p=0.029$, dry; $p=0.000$, rainy; $a=0.05$ ) and over the seasons (t-test; $p=0.000 ; a=0.05)$, but not along the depth in rainy (Kruskal-Wallis test; $\mathrm{p}=0.472 ; \mathrm{a}=0.05$ ) and dry season (ANOVA test; $\mathrm{p}=0.406$; $a=0.05$ ). The highest values for turbidity were observed during the dry season ( 72.3 to 3120.0 UNT) in the P1, when compared to the profiles over the rainy season (10.9 a 3001,0 UNT). Statistical analyses indicated a significant difference over the seasons (t-test; $p=0.008$; $a=0.05$ ) and profiles in each season (t-test; $p=0.020$, dry; $p=0.016$, rainy; $a=0.05$ ), but not among the depths of each season (Kruskal-Wallis test; $p=0.911$, dry; $p=0.288$, rainy; $a=0.05$ ).

\section{NUTRIENT FLUXES VARIABILITY}

The rainy season showed highest nitrite fluxes in the profile P1, while the dry season were higher in the profile P2. Nitrite fluxes average for the dry season ranged from 0.05 to $1.06 \mathrm{~kg} \mathrm{~s}$ 1 , with an increase of $18.6 \%$ in the flux from P1 to P2 (Fig. 4). The flux decreased $44.9 \%$ from P1 to P2 throughout the rainy season, with the range of 0.00 to $1.57 \mathrm{~kg} \mathrm{~s}^{-1}$ in this season. Statistical analyses showed significant difference between the profiles in each season ( $t$-test; $p=0.001$, dry; $p=0.041$, rainy; $a=0.05$ ), but not throughout the depths (Kruskal-Wallis test; $p=0.793$, dry; $p=0.721$, rainy; $a=0.05$ ) and over the seasons ( $t$-test; $p=0.067 ; a=0.05$ ).

Over the dry season, phosphate fluxes average ranged from 2.49 to $9.96 \mathrm{~kg} \mathrm{~s}^{-1}$ with only $0.3 \%$ spatial variation long the profiles. The rainy season showed values varied from 2.95 to $24.00 \mathrm{~kg} \mathrm{~s}^{-1}$, which $70.4 \%$ of the phosphate originated from river discharge do not reach the profile P2 (Fig. 5). This variability was confirmed by statistical analyses that identified a significate difference of the phosphate fluxes between the seasons ( $t$-test; $p=0.000 ; a=0.05$ ) and the profiles in each campaign ( $t$-test; $p=0.000$, dry; $p=0.000$, rainy; $a=0.05$ ), but not among the depths (Kruskal-Wallis test; $p=0.953$, dry; $p=0.708$, rainy; $a=0.05$ ).

Silicate fluxes average ranged from 93.69 to $307.28 \mathrm{~kg} \mathrm{~s}^{-1}$ over the dry season, while values observed during the rainy season varied from 40.03 to $402.76 \mathrm{~kg} \mathrm{~s}^{-1}$ (Fig. 6). Spatial variations throughout the profiles were almost constant, obtaining the highest flux at P1 that decrease towards to P2. The flux decreased from P1 to P2 in both seasonal periods, represented $15.4 \%$ in the dry season and $76.2 \%$ in the rainy season. Although, as observed for phosphate flux, it also had significate differences between the profiles (t-test; $p=0.000$, dry; $p=0.000$, 
rainy; $\mathrm{a}=0.05$ ) and seasons (t-test; $\mathrm{p}=0.022 ; \mathrm{a}=0.05$ ), but not along the water column (Kruskal-Wallis test; $p=0.849$, dry; $p=0.788$, rainy; $a=0.05$ ).
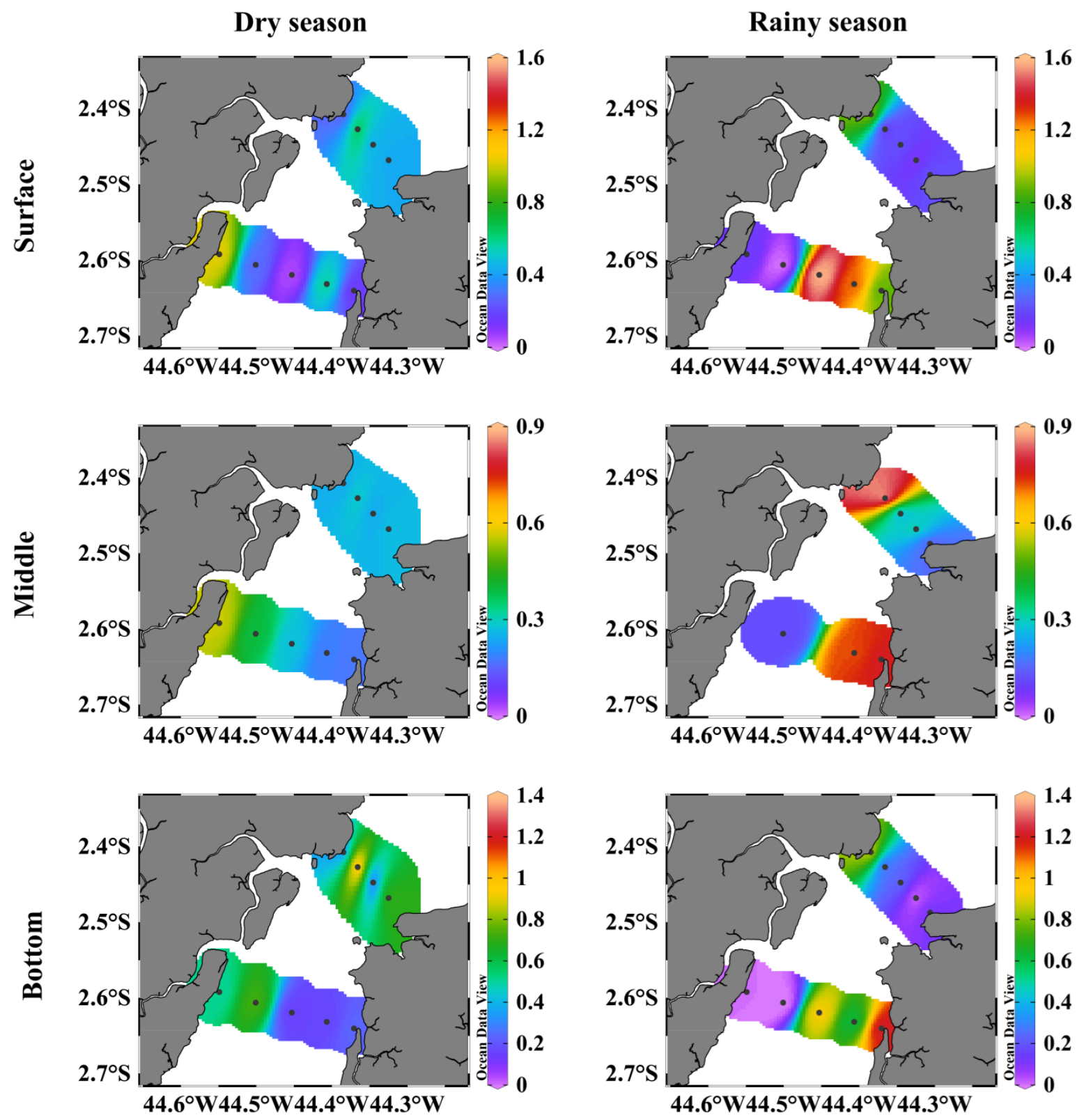

Figure 4. Nitrite flux average (kg s-1) in the three depths of São Marcos Bay water column, during the dry and rainy seasons. 

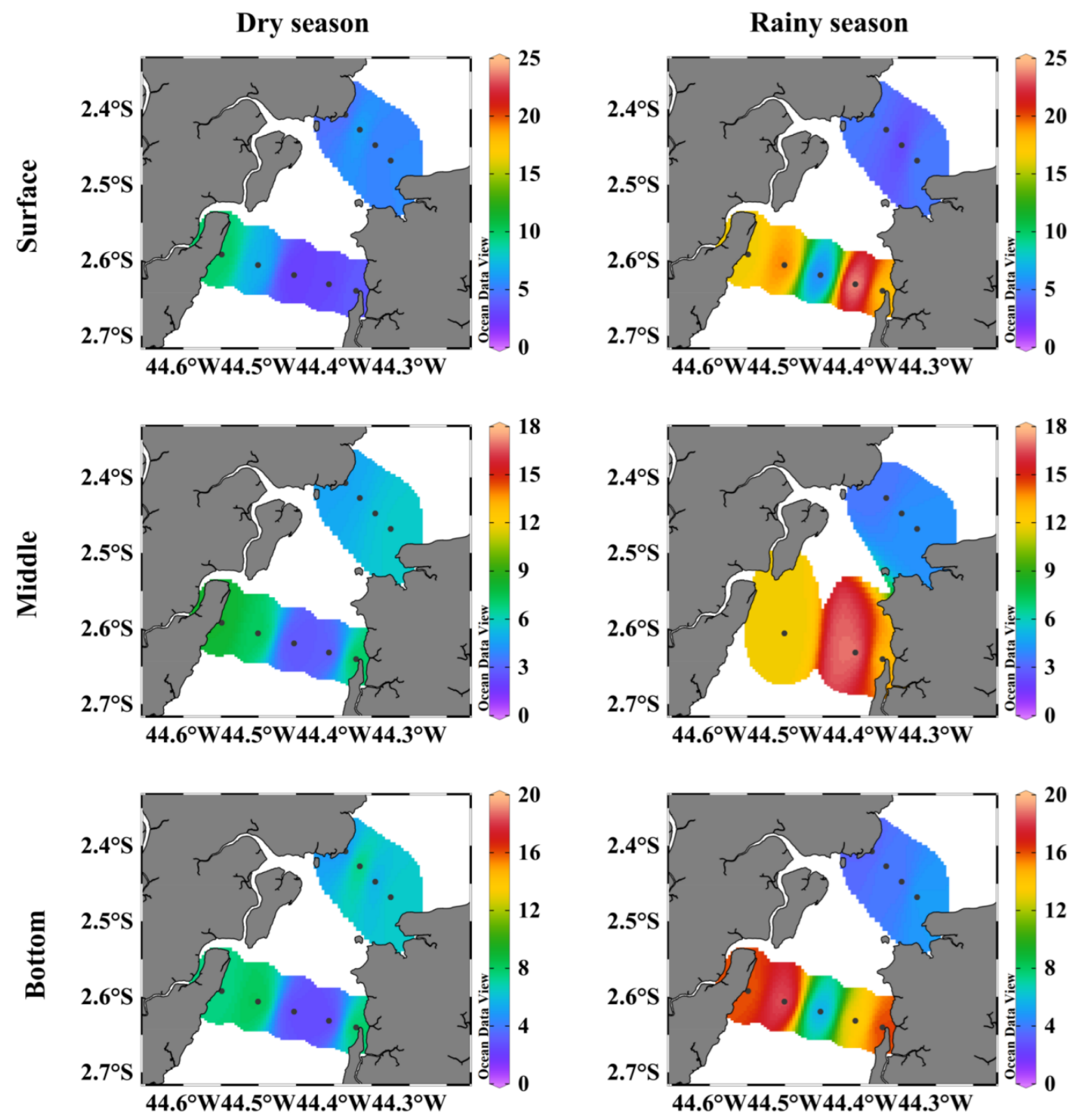

Figure 5. Phosphate flux average ( $\mathrm{kg} \mathrm{s}-1$ ) in the three depths of São Marcos Bay water column, during the dry and rainy seasons. 

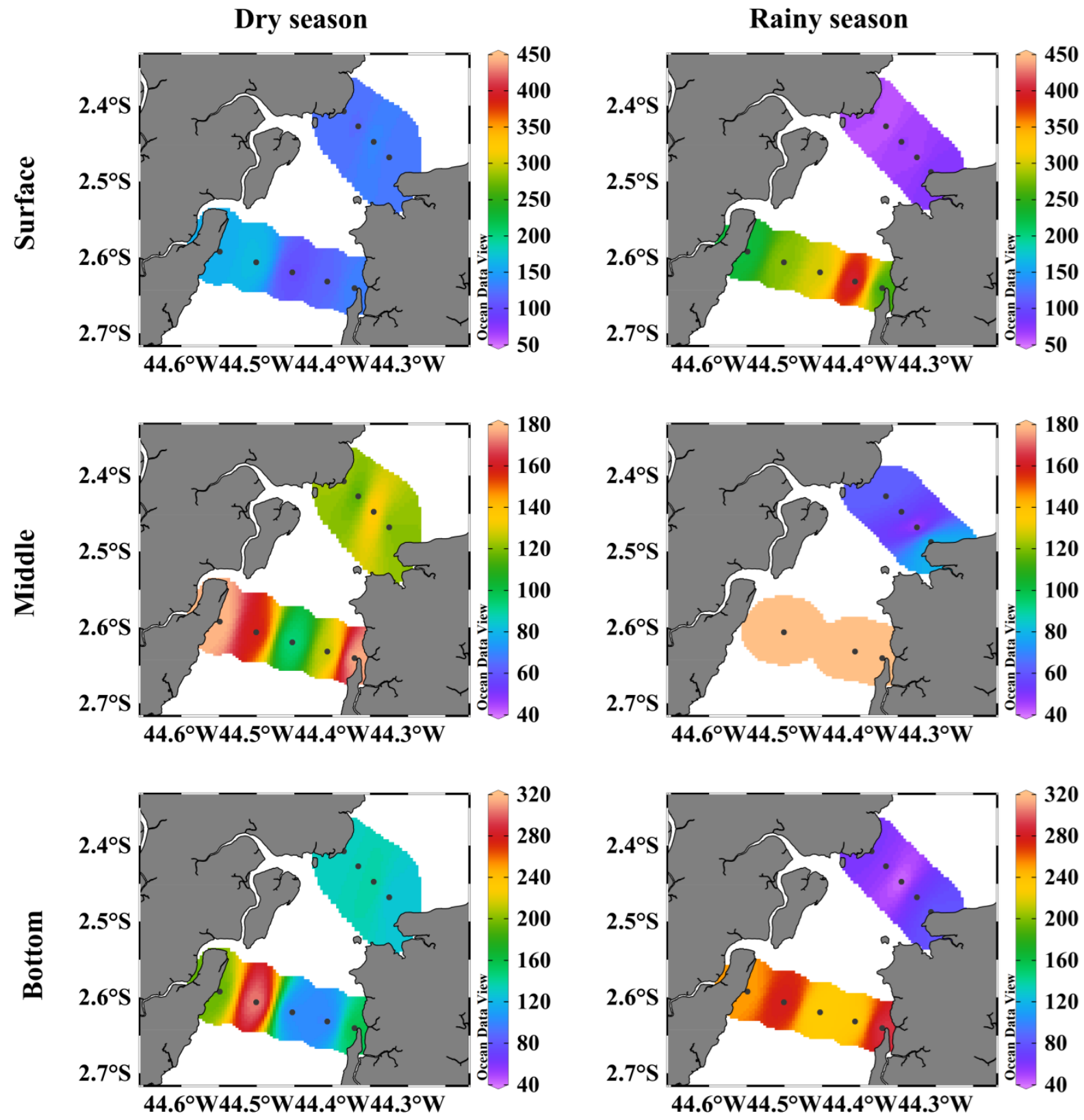

Figure 6. Silicate flux average $\left(\mathrm{kg} \mathrm{s}^{-1}\right)$ in the three depths of São Marcos Bay water column, during the dry and rainy seasons.

\section{PRINCIPAL COMPONENT ANALYSIS (PCA)}

The result for each season is showed in the graphs below (Fig. 7). The PCA for the dry season showed Factor 1 explained $36.44 \%$ of the data, where salinity and $\mathrm{pH}$ were positively related to each other, and inversely with turbidity and dissolved nutrients. Factor 2 explained $26.19 \%$ of the variations. It showed that temperature and DO influence almost all factors used in the analyze (Tab. 1 ). The sum of the factors for this season was $62.63 \%$, showing that there 
may be other parameters that demonstrate the oscillation of these variables in the environment.

The rainy season PCA graph indicated $44.93 \%$ of the data was explained in the Factor 1 , which DO have an inverse correlation with the other parameters. Factor 2 explained $26.18 \%$ of the variations, showing that $\mathrm{pH}$, turbidity and dissolved nutrients were positively influenced by DO (Tab. 1). The total sum of the factors was $71.01 \%$, demonstrating that these variables have strong influence on the oscillation of the parameters in the environment.

\begin{tabular}{ccccc}
\hline \multirow{2}{*}{ Variables } & \multicolumn{2}{c}{ Dry Season } & \multicolumn{2}{c}{ Rainy Season } \\
& Factor 1 & Factor 2 & Factor 1 & Factor 2 \\
\hline Temperature & -0.51 & 0.60 & - & - \\
Salinity & 0.61 & -0.65 & - & - \\
Turbidity & -0.78 & -0.06 & 0.80 & 0.03 \\
pH & 0.82 & -0.17 & -0.60 & 0.54 \\
DO & -0.11 & 0.63 & 0.62 & -0.72 \\
Phosphate & -0.56 & -0.63 & 0.82 & 0.53 \\
Nitrate & -0.46 & -0.59 & 0.78 & 0.30 \\
Silicate & -0.67 & -0.36 & 0.12 & 0.62 \\
Eigenvalues & 2.92 & 2.10 & 2.70 & 1.56 \\
\% of Variance & 36.44 & 26.19 & 44.93 & 26.08 \\
\hline
\end{tabular}

Table 1. Factor coordinates of the variables and eigenvalues obtained by Principal Component Analysis (PCA) of the physical-chemical parameters of the water column in São Marcos Bay.

Figure 7. Principal components analysis (PCA) of the physical-chemical parameters of the water column of the sample profiles in São Marcos Bay in a) dry season and in b) rainy season.
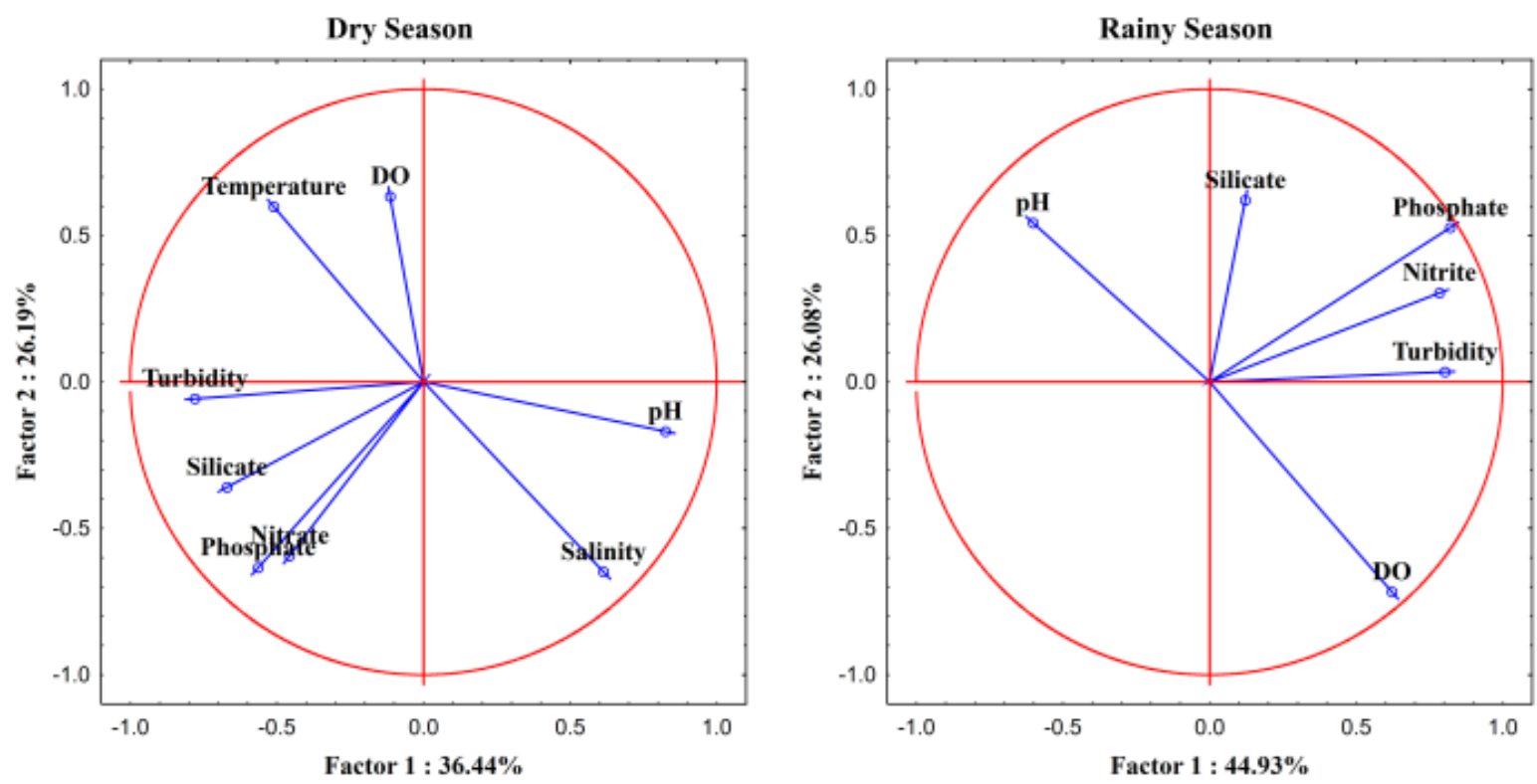

Tropical Oceanography, Recife, v. 48, n. 1, p. 1-19, 2020. 


\section{DISCUSSION}

The increase in water discharge followed seasonal proportionality, where the highest values were found during the rainy season (Falco et al., 2010; Monteiro et al., 2015). Although rainfall recorded in the two campaigns was below the monthly mean historical rainfall, that direct interfere in the temporal variation of the flux in SMB. In comparison to other rivers in the tropical equatorial region, the SMB water discharge is two orders of magnitude lower than Amazon River, $1.93 \times 10^{5} \mathrm{~m}^{3} \mathrm{~s}^{-1}$, and one order of magnitude above Arraial Bay Estuarine Complex, with $2.81 \times 10^{4} \mathrm{~m}^{3} \mathrm{~s}^{-1}$ of water discharge during the spring tide (Noriega et al., 2005; Serejo et al., 2020).

Homogeneity of temperature over the seasons was typical of estuaries located in the tropical regions, where the air temperature almost not change over the year. Similar variability was also observed in other study in the same area (Corrêa et al., 2019). Temperature variability over the water column is may associated with the local depth that permit a vertical gradient during the dry season. The low salinity values at two sites of $\mathrm{P} 2$ can be related to ebb tide condition during the sampling time. Nevertheless, the not significant variability along the depths indicates the predominate seawater influence inside of the environment. According to Azevedo et al. (2008), the salinity regime in Golfão Maranhense estuaries varies seasonally from mesohaline during the rainy season to euhaline throughout the dry season, although this seasonal variability could not be observed, in our study, due to the data lack.

The special variability of $\mathrm{pH}$ between the profiles ( $\mathrm{P} 1$ to $\mathrm{P} 2$ ) was consequence of the change from ebb tide to flood tide. It changed the fluvial discharge to seawater entrance in SMB, that showed alkalinity conditions as observed in previous study (Azevedo et al., 2008). The $\mathrm{pH}$ influences the solubility of chemical constituents, biological and nutrient availability $(P$, $\mathrm{N}$ and $\mathrm{C}$ ). Also, it can be altered by factors such as photosynthesis, the flow and reflux of seawater and a decomposition of organic matter (Corrêa et al., 2019; Rahaman et al., 2013). The values observed in the present study presents the same range of $\mathrm{pH}(6.5-8.5)$ indicated by the CONAMA Resolution No 357 (2005) for brackish water quality conditions.

The DO results present values below to the CONAMA Resolution No 357 (2005) for brackish water quality conditions, with the concentration should be higher than $5.0 \mathrm{mg} \mathrm{L}^{-1}$. Low DO contents is a direct result to the decomposition of organic matter by aerobic bacteria (Sakamaki et al., 2006), which the great mangrove forest of the region (Rodrigues et al., 2016) acts as the main source of organic matter to the water column. These DO values may also be a natural condition of the estuarine ecology (Calazans, 2011), such as in estuaries with high temperature and constant tidal variation, as observed in the present study (Azevedo et al., 2008). Therefore, it made SMB a self-depleting environment, without cause oxygen deficit to biochemistry processes. 
Higher turbidity values throughout the dry season may be associated with water evaporation and wind speed intensification characteristic for this season, that can resuspend the sediment from the bottom. Notwithstanding, the highest values of turbidity was observed during the rainy season for Serejo et al. (2020), which was attributed to the increase of continental material input due to the rainfalls. Fine-grained size, microscopic organisms, organic and inorganic matter are the mainly material that compose the suspended solid and cause the turbidity in the water (Calazans, 2011).

Nutrient fluxes increase was correlated to seasonal variability of fluvial discharges. When the rainfall raised in the draining basin, the material fluxes to the coastal environment also intensified (Noriega et al., 2005; Silva et al., 2015). In a well-mixed estuary, such as SMB, the influence of the tide was intense and presents a small freshwater inflow. It caused the homogeneous nutrient distribution, and made it act as a source of nutrients after the internal transformations in the system (Silva, 2007).

The increase of nitrite flux from upstream to downstream (P1 to P2) during the dry season, may indicate that SMB can act as a source of nitrite for the adjacent region, while the rainy season was observed a different distribution that decreased in the middle of the environment. It may be the result of physical-chemical and biological processes that change the nitrite into nitrogenous forms most stables present in the environment, such as ammonium and nitrate (Silva et al., 2015; Statham, 2012). The inverse condition was observed in a macrotidal estuary of the Jiulong River, that exported nitrite to the marine system (Yan et al., 2012).

The accumulation of nitrite in the water column can be resulted of biological reduction of nitrate (NO3) by bacteria of the species Pseudomonas in environments under low DO values ( Grasshoff et al., 1999; Riley and Chester, 1971; Silva, 2007). Nitrite input in the water column can also occur indirectly by the sediment of the mangrove, as observed in SMB during dry season. The mangrove sediment is rich in organic matter that produces ammonium (NH3-) when it degraded and by DO availability in the water, it is converted to nitrate (NO3-). The amount of nitrite is proportional to the other forms of nitrogen. Usui et al. (2001) observed in Tama estuary (Japan) a change in the environmental metabolism. It caused the denitrification process of nitrous oxide (N2O) present in the sediment, acting as a nitrogen source for the conversion of NO2- and NO3- to aquatic environment.

Phosphate in the water was contained in the estuary throughout the rainy season, making SMB a sink of this nutrient. It may be correlated to the biogeochemical processes of photosynthetic assimilation, adsorption of particulate matter, flocculation and sedimentation of the detrital phosphorus, and phosphorus associated with inorganic compounds or with allochthonous organic matter (Eschrique, 2011; Gilbert et al., 2010; Souza et al., 2009). However, it was not observed a sinking behavior for phosphate in the macrotidal estuary in Colorado River Delta (Carriquiry et al., 2011). 
The phosphate increased during the rainy season in association to anthropic activities that occurred in the drainage basin. Soil erosion and leaching, domestic and industrial effluents, agricultural and livestock activities, with excessive use of fertilizers are the main activities developed this region (Guidolini et al., 2010). Periodic dredging in the port area is commonly performed at SMB to preserve the depths of the channels for navigation. This process mobilizes the sediment from the bottom to water column, making phosphorus available to the environment. Phosphate in high concentrations occasion large production of organic matter causing eutrophication of the environment (Braga and Chiozzini, 2006; Eschrique, 2011).

Silicate flux average exhibited highest values in the innermost portion of the estuary during the dry season. This nutrient almost exclusively derived from chemical weathering of rocks and soils, being a strong indicator of terrestrial contribution and dilution processes (Braga and Chiozzini, 2006; Falco et al., 2010; Riley and Chester, 1971). Therefore, the high concentration of silicate upstream of SMB may be related to the erosive processes that occur in the margins of the environment, deforestation for agriculture and urbanization (Chen et al., 2014). As well the resuspension of the bottom material due to dredging of the port area.

The retention of silicate in the environment was associated to silica removal processes from water column, such as the assimilation by the primary production (diatoms) and sedimentation of biogenic silica (Chen et al., 2014; Fagherazzi et al., 2013; Riley and Chester, 1971). Changes on silica concentrations in the aquatic environment may modified the distribution and abundance of diatom species, altering the structure composition of tropical and subtropical ecosystems ( $\mathrm{Li}$ et al., 2007). However, the sink behavior for silicate was not observed in Colorado River Delta and Jiulong River estuary (Carriquiry et al., 2011; Yan et al., 2012).

The dry season PCA graph showed the influence of seawater inside SMB. When the flood tide entered the estuary, salinity and $\mathrm{pH}$ increased while the other variables decreased due the processes that occur in the water column. These processes were commonly related to acidbase reactions and those of oxidation-reduction of the environment of materials dissolved in water, such as dissolved nutrients and colloids that interfered on water turbidity (Fiorucci and Benedetti Filho, 2005). Rainy season PCA graph showed an environment with inverse conditions to those observed during the dry season. The $\mathrm{pH}$ of the environment was reduced by the dilution of seawater by the increase of the fluvial discharge, that increased OD, nutrients and turbidity in the environment.

In estuaries strongly influenced by seawater, such as SMB, there was a greater water exchange that favors the dilution of nutrients. This condition added to the great distance of the main nutrient sources leads to lower concentrations of nutrients downstream (Silva et al., 2015), as observed in the present study. However, in other estuary influenced by tidal was not found evidence of nutrient removal (Uncles et al., 2003). 


\section{CONCLUSION}

São Marcos Bay presented typical characteristic of tropical equatorial estuary with strong influence of the marine forces in the estuarine system. Water discharge had a seasonal variation with values of two orders of magnitude below the Amazon River, which influence the distribution of nutrients dissolved in the environment. The variability of nutrient fluxes throughout the seasons demonstrated São Marcos Bay develop predominantly an important role as a nutrient sink in the transition interface between the continent and ocean of the Brazilian Amazonian region.

\section{ACKNOWLEDGMENTS}

The authors are grateful to Audálio Rebelo Torres Junior and Francisco José da Silva Dias for their invitation to participate in the Project of Monitoring the Quality of Coastal Waters and Marine Sediments. We are really grateful to all members of Laboratório de Biogeociclos dos Componentes Químicos da Água (Labciclos) and Laboratório de Hidrodinâmica Costeira, Estuarina e de Águas Interiores (LHiCEAI) for the field and laboratory support.

\section{REFERENCES}

Azevedo, A.C.G. de, Feitosa, F.A.N. and Koening, M.L. (2008), Distribuição espacial e temporal da biomassa fitoplanctônica e variáveis ambientais no Golfão Maranhense, Brasil, Acta Botanica Brasilica, Vol. 22, pp. 870-877.

Berbel, G.B.B. (2008), Estudo do fósforo sedimentar e de suas especiações químicas em dois sistemas costeiros e Plataforma Continental Sudeste (Brasil) e Baía do Almirantado (região Antártica) considerando suas relações biogeoquímicas, São Paulo, Tese de Doutorado, Programa de Pós-graduação em Oceanografia Química e Geológica, Instituto Oceanográfico, Universidade de São Paulo, 95p.

Braga, E.S. and Chiozzini, V.G. (2006), Nutrientes dissolvidos no complexo estuarino de Cananéia- Iguape: influência dos Valo Grande no Setor Sul (1992 e 2005), in: III Simpósio Brasileiro de Oceanografia. São Paulo, Brasil, pp. 573-582.

Calazans, D.K. (2011), Estudos Oceanográficos: do instrumental ao prático, 1a. ed. Editora Textos, Pelotas, RS, 463p.

Carriquiry, J.D., Villaescusa, J.A., Camacho-Ibar, V., Daesslé, L.W. and Castro-Castro, P.G. (2011), The effects of damming on the materials flux in the Colorado River delta, Environmental Earth Science, Vol. 62, pp. 1407-1418. 
Cavalcanti, L.F., Azevedo-Cutrim, A.C.G., Oliveira, A.L.L., Furtado, J.A., Araújo, B. de O., Sá, A.K.D.-S., Ferreira, F.S., Santos, N.G.R., Dias, F.J.S. and Cutrim, M.V.J. (2018), Structure of microphytoplankton community and environmental variables in a macrotidal estuarine complex, São Marcos Bay, Maranhão - Brazil, Brazilian Journal of Oceanography, Vol. 66, pp. 283-300.

Chagas, F.M. (2013), Dinâmica de ondas de areia na Baía de São Marcos (Ponta da Madeira/MA): observações e modelagem numérica, São Paulo, Dissertação de Mestrado, Programa de Pós-graduação em Oceanografia Geológica, Instituto Oceanográfico, Universidade de São Paulo, 93p.

Chen, N., Wu, Y., Wu, J., Yan, X. and Hong, H. (2014), Natural and human influences on dissolved silica export from watershed to coast in Southeast China, Journal of Geophysical Research: Biogeosciences, Vol. 119, pp. 85-109.

Conselho Nacional do Meio Ambiente (CONAMA) (2005). Resolução No 357, de 15 de março de 2005 - Dispõe sobre a classificação dos corpos de água e diretrizes ambientais para o seu enquadramento, bem como estabelece as condições e padrões de lançamento de efluentes, e dá outras providências, in: http://www.mma.gov.br/conama (access in September 15, 2015).

Corrêa, M., Serejo, J., Rangel, T., Oliveira, B., Almeida, M., Dias, F., Rezende, C. (2019). Caracterização biogeoquímica da matéria orgânica em um estuário de macromaré localizado na interface Amazônia-semiárido no nordeste do Brasil, Geochimica Brasiliensis, Vol. 33, pp. 107-120.

De Carvalho, G.P., Cavalcante, P.R., de Castro, A.C. and Rojas, M.O. (2000), Preliminary assessment of heavy metal levels in Mytella falcata (Bivalvia, Mytilidae) from Bacanga River estuary, São Luís, state of Maranhão, northeastern Brazil, Revista Brasileira de Biologia, Vol. 60, pp. 11-16.

De Morais, J.O. (1977), Processos de Sedimentação na Baía de São Marcos, Estado do Maranhão, Brasil, Arquivo de Ciências Mar, Vol. 17, n. 2, pp. 153-164.

Demaster, D.J., Pope, R.H. (1996). Nutrient dynamics in Amazon shelf waters: results from AMASSEDS. Continental Shelf Research, Vol. 16, pp. 263-289.

El-Robrini, M., Valter Marques, J., Silva, M.A.M.A. da, Robrini, M.H.S.E., Feitosa, A.C., Tarouco, J.E.F., Santos, J.H.S. dos and Viana, J.R. (2006), Maranhão, in: Muehe, D. (Ed.), Erosão e Progradação Do Litoral Brasileiro, Brasília, pp. 87-130.

Eschrique, S.A. (2011), Estudo do balanço biogeoquímico dos nutrientes dissolvidos principais como indicador da influência antrópica em sistemas estuarinos do nordeste e sudeste do 
Brasil, São Paulo, Tese de Doutorado, Programa de Pós-graduação em Oceanografia Química e Geológica, Instituto Oceanográfico, Universidade de São Paulo, 231p.

Fagherazzi, S., Wiberg, P.L., Temmerman, S., Struyf, E., Zhao, Y. and Raymond, P.A. (2013), Fluxes of water, sediments, and biogeochemical compounds in salt marshes, Ecological Processes, 2: 3p.

Falco, S., Niencheski, L.F., Rodilla, M., Romero, I., González del Río, J., Sierra, J.P. and Mösso, C. (2010), Nutrient flux and budget in the Ebro estuary, Estuarine, Coastal and Shelf Science, Vol. 87, pp. 92-102.

Feres, S.J.C. (2010), Organismos exóticos: uma ameaça a sustentabilidade ambiental do Golfão Maranhense, São Luís, Dissertação de Mestrado, Programa de Pós-graduação em Sustentabilidade de Ecossistemas, Universidade Federal do Maranhão, 120p.

Fiorucci, A.R. and Benedetti Filho, E. (2005), Oxigênio dissolvido: propriedades e solubilidade, Química Nova na Escola, Vol. 22, pp. 10-16.

Gilbert, P.M., Madden, C.J., Boynton, W., Flemer, D., Heil, C. and Sharp, J. (2010), Nutrients in estuaries: a summary report of the National Estuarine Experts Workgroup (2005-2007), National Estuarine Experts, Washington, D.C, 188p.

González-Gorbeña, E., Rosman, P.C.C. and Qassim, R.Y. (2015), Assessment of the tidal current energy resource in São Marcos Bay, Brazil, Journal of Ocean Engineering and Marine Energy, Vol. 1, pp. 421-433.

Grasshoff, K., Kremling, K. and Ehrhardt, M. (1999), Methods of Seawater Analysis, 3rd ed. Wiley-VCH, Weinheim . New York. Chichester. Brisbane. Singapore. Toronto, 600p.

Guidolini, J.F., Abdala, V.L., Carmo, D.A. Do, Val, B.H.P. and Valle Junior, R.F. (2010), Ortofosfato como parâmetro indicador de qualidade da água em diferentes pontos da bacia do rio Uberaba, in III Seminário Iniciação Científica e Inovação Tecnológica, pp. 13.

Howarth, R., Chan, F., Conley, D.J., Garnier, J., Doney, S.C., Marino, R., Billen, G. (2011). Coupled biogeochemical cycles: Eutrophication and hypoxia in temperate estuaries and coastal marine ecosystems, Ecological Society of America, Vol. 9, pp. 18-26.

Li, M., Xu, K., Watanabe, M. and Chen, Z. (2007), Long-term variations in dissolved silicate, nitrogen, and phosphorus flux from the Yangtze River into the East China Sea and impacts on estuarine ecosystem, Estuarine, Coastal and Shelf Science, Vol. 71, pp. 3-12.

Miranda, L.B., Castro, B.M. and Kjerfve, B. (2012), Princípios de Oceanografia Física de Estuários, EDUSP, São Paulo, Brasil, 480p. 
Monteiro, S. de M., El-Robrini, M., Alves, I.C.C. (2015), Dinâmica sazonal de nutrientes em estuário Amazônico, Mercator, Vol. 14, pp. 151-162.

Noriega, C.D., Muniz, K., Araújo, M.C., Travassos, R.K. and Neumann-Leitão, S. (2005), Fluxos de nutrientes inorgânicos dissolvidos em um estuário tropical - Barra das Jangadas - PE, Brasil, Tropical Oceanography, Vol. 33, pp. 133-145.

Pereira, F.B.P. (2012), Oxigênio dissolvido como indicador de processos biogeoquímicos e de mudanças globais em estuários, Monografia de Conclusão de Curso, Curso Bacharel em Oceanografia, Instituto Oceanográfico, Universidade de São Paulo, 56p.

Rahaman, S.B., Sarder, L., Rahaman, S., Ghosh, A.K., Biswas, S.K. and Huq, S.S.S.K.A., Hasanuzzaman, A.F.M., Islam, S.S. (2013), Nutrient dynamics in the Sundarbans mangrove estuarine system of Bangladesh under different weather and tidal cycles, Ecological Processes, Vol. 29, pp.1-13.

Riley, J.P. and Chester, R. (1971), Introduction to marine chemistry, Academic P. ed. Academic Press, London and New York, 465p.

Rodrigues, C.A.L., Ribeiro, R.P., Santos, N.B. and Almeida, Z.S. (2016), Patterns of mollusc distribution in mangroves from the São Marcos Bay, coast of Maranhão State, Brazil, Acta Amazonica, Vol. 46, pp. 391-400.

Sakamaki, T., Nishimura, O., Sudo, R. (2006). Tidal time-scale variation in nutrient flux across the sediment-water interface of an estuarine tidal flat, Estuarine, Coastal and Shelf Science, Vol. 67, pp. 653-663.

Sant'Ana Júnior, H.A. (2016), Complexo portuário, reserva extrativista e desenvolvimento no maranhão, Caderno CPRH, Vol. 29, pp. 281-294.

Serejo, J.H.F., Santos, T.T.L., Lima, H.P., Azevedo, I.H.R., Dos Santos, V.H.M., Eschrique, S.A. (2020). Fortnightly variability of total suspended solids and bottom sediments in a macrotidal estuarine complex on the Brazilian northern coast, Journal of Sedimentary Environments, Vol. 5, pp. 101-115.

Silva, M.A.M. (2007), Biogeoquímica dos nutrientes inorgânicos dissolvidos e biomassa fitoplanctônica no estuário do Rio Cachoeira, Ilhéus, Bahia, Dissertação de Mestrado, Programa de Pós-Graduação em Sistemas Aquáticos Tropicais, Universidade Estadual de Santa Cruz, 123p.

Silva, M.A.M. Souza, M. L. and Abreu, P.C., (2015), Spatial and temporalvariation of dissolved inorganic nutrients, and chlorophyll-a in a tropical estuary in northeastern Brazil: Dynamics of nutrient removal, Brazilian Journal of Oceanography, Vol. 63, pp. 1-15. 
Souza, M.F.L. de, Eça, G.F., Silva, M.A.M., Amorim, F.A.C. and Lôbo, I.P. (2009), Distribuição de nutrientes dissolvidos e clorofila-a no estuário do rio Chachoeira, nordeste do Brasil, Atlântica, Vol. 31, pp. 107-121.

Statham, P.J. (2012), Nutrients in estuaries - An overview and the potential impacts of climate change, Science of the Total Environment, Vol. 434, pp. 213-227.

Teixeira, S.G. and Souza Filho, P.W.M.E. (2009), Mapeamento de ambientes costeiros tropicais (Golfão Maranhense, Brasil) utilizando imagens de sensores remotos orbitais, Revista Brasileira de Geofísica, Vol. 27, pp. 69-82.

Uncles, R.J., Frickers, P.E. and Harris, C. (2003), Dissolved nutrients in the Tweed Estuary, UK: Inputs, distributions and effects of residence time, Science of the Total Environment, Vol. 314, pp. 727-736.

Usui, T., Koike, I. and Ogura, N. (2001), $\mathrm{N}_{2} \mathrm{O}$ Production, Nitrification and Denitrification in an Estuarine Sediment, Estuarine, Costal and Shelf Science, Vol. 10, pp. 769-781.

Wang, X., Yu, Z., Fan, W. and Song, X. (2014), Nutrient fluxes in the Changjiang River estuary and adjacent waters-a modified box model approach, Chinese Journal of Oceanology and Limnology, Vol. 33, pp. 176-193.

Yan, X.L., Zhai, W.D., Hong, H.S., Li, Y., Guo, W.D. and Huang, X. (2012), Distribution, fluxes and decadal changes of nutrients in the Jiulong River Estuary, Southwest Taiwan Strait, Chinese Science Bulletin, Vol. 57, pp. 2307-2318. 